Original

\title{
Association analysis between genetic variants of MDM2 gene and osteosarcoma susceptibility in Chinese
}

\author{
Jinshan $\mathrm{He}^{1)}$, 2), Jingcheng Wang ${ }^{1)}$, Daxin Wang ${ }^{1)}$, Shanhe Dai ${ }^{1)}$, Tangyun $\mathrm{Yv}^{1)}$, Pengtao Chen ${ }^{1)}$, \\ Renshi $\mathrm{Ma}^{1)}$, Chunyv Diao ${ }^{1)}$ and Guohua $\mathrm{Lv}^{2}$ ) \\ ${ }^{1)}$ Department of Orthopedics, Subei People’s Hospital, Clinical Medical School of Yangzhou University, Yangzhou 225001, \\ People's Republic of China \\ 2) Department of Spine, The Second Xiangya Hospital Affiliated with Central South University, Changsha 410011, People's \\ Republic of China
}

\begin{abstract}
Osteosarcoma (OS) is the most common pediatric bone malignancy worldwide. The MDM2 gene is an important candidate gene for influencing the susceptibility to OS. The objective of this study aimed to detect the potential association between MDM2 genetic variants and OS susceptibility in Chinese Han population. We recruited 415 OS patients and 431 cancer-free controls in this case-control study. The c.44C $>\mathrm{T}$ and c.1002T $>\mathrm{C}$ genetic variants in $M D M 2$ gene were investigated using created restriction site-polymerase chain reaction (CRS-PCR) and PCR-restriction fragment length polymorphism (PCR-RFLP), respectively. We found that the genotypes/alleles of c. $44 \mathrm{C}>\mathrm{T}$ and c. $1002 \mathrm{~T}>\mathrm{C}$ were statistically associated with the increased risk of OS (for c. $44 \mathrm{C}>\mathrm{T}$, TT versus (vs.) CC: $\mathrm{OR}=2.43,95 \% \mathrm{CI} 1.49-3.95, p<0.001$; $\mathrm{T} v s$. $\mathrm{C}: \mathrm{OR}=1.36,95 \%$ CI 1.11-1.67, $p=0.003$; for c. $1002 \mathrm{~T}>\mathrm{C}, \mathrm{CC} v s$. TT: OR $=2.38,95 \% \mathrm{CI} 1.37-4.13, p=0.002 ; \mathrm{C} v s$. T: $\mathrm{OR}=1.27,95 \% \mathrm{CI} 1.02-1.56, p=0.030$ ). The $\mathrm{T}$ allele and TT genotype of $\mathrm{c} .44 \mathrm{C}>\mathrm{T}$ and $\mathrm{C}$ allele and $\mathrm{CC}$ genotype of c. $1002 \mathrm{~T}>\mathrm{C}$ could be increased risk factors for the susceptibility to OS. Results from this study suggest that MDM2 genetic variants are potentially related to OS susceptibility in Chinese Han population, and might be used as molecular markers for assessing OS susceptibility.
\end{abstract}

Key words: Osteosarcoma, MDM2 gene, Genetic variants, Molecular markers, Susceptibility

OSTEOSARCOMA (OS) is the most common pediatric bone malignancy that occurs primarily in adolescents and young adults in the world [1-5]. The exact mechanism of development of OS carcinogenesis still remains poorly understood. Patients with localized OS at presentation have a $60-80 \%$ rate of long-term survival, while metastatic disease carries a poorer prognosis $[6,7]$. It is estimated that the annual incidence rate for individuals less than 20 years old is 8.7 per million children, and account for $\sim 6 \%$ of childhood cancer $[8,9]$. Several studies suggest that multiple factors such as genetic mutations and environment factors could affect the OS pathogenesis. However, the genetic factors could play key roles in the pathogenesis of OS [9-15]. There are several studies indicate that the MDM2 gene is an important candidate

Submitted Jun. 21, 2013; Accepted Jul. 12, 2013 as EJ13-0260 Released online in J-STAGE as advance publication Aug. 9, 2013

Correspondence to: Pengtao Chen, Department of Orthopedics, Subei People's Hospital, Clinical Medical School of Yangzhou University, No. 98 Nantong West Road, Yangzhou 225001, Jiangsu Province, People's Republic of China E-mail: pengtao_chen@sina.com gene for influencing the susceptibility to OS [16-21]. The single nucleotide polymorphisms (SNPs) in MDM2 gene (such as rs2279744 (T309G) and rs1690916) have been analyzed the potential association with OS susceptibility and might have influences on the development of OS [16-19]. However, the association of MDM2 genetic variants with OS occurrence is not well understood. Up to now, the potential association of c. $44 \mathrm{C}>\mathrm{T}$ and c. $1002 \mathrm{~T}>\mathrm{C}$ genetic variants in $M D M 2$ gene with the susceptibility to OS have not been reported. Thus, the objective of this study aimed to investigate the distribution of $M D M 2 \mathrm{c} .44 \mathrm{C}>\mathrm{T}$ and c. $1002 \mathrm{~T}>\mathrm{C}$ genetic variants and to assess whether these genetic variants influence on OS susceptibility in Chinese Han population.

\section{Materials and Methods}

\section{Study population}

A total of 415 diagnosed OS patients (aged 10-68 years old) and 431 healthy subjects (aged 12-67 years old) who had no history of OS as controls were recruited 
from the Second Xiangya Hospital Affiliated with Central South University between January 2004 and December 2012. All subjects were unrelated Chinese with Han nationality and lived in Changsha city of China. The cancer-free controls were matched with OS patients with regards to gender, age and residence area (urban or rural). Table 1 shows the general characteristics, including gender, sex, tumor location, and metastasis. The written informed consent was obtained from each participant. The protocol of this study was approved by the Ethics Committee of Second Xiangya Hospital Affiliated with Central South University.

\section{DNA extraction and PCR amplification}

Gnomic DNA was extracted from peripheral venous blood using the blood genomic DNA miniprep kit
(Axygen Biosciences) according to the manufacturer's instructions. Based on the mRNA sequences (GenBank ID: NM_002392.4) and DNA sequences (GenBank ID: NG_016708.1) of the human MDM2 gene, two pair of primers were designed by the Primer Premier 5.0 software (PREMIER Biosoft International, Palo Alto, CA). Table 2 shows the primers sequences, annealing temperature, fragment sizes and region. The polymerase chain reaction (PCR) reaction was performed in a total volume of $20 \mu \mathrm{L}$ solution containing 50ng template DNA, $1 \times$ buffer (Tris- $\mathrm{HCl} 100 \mathrm{mmol} / \mathrm{L}$, $\mathrm{pH} 8.3 ; \mathrm{KCl} 500 \mathrm{mmol} / \mathrm{L}), 0.25 \mu \mathrm{mol} / \mathrm{L}$ primers, 2.0 $\mathrm{mmol} / \mathrm{L} \mathrm{MgCl}_{2}, 0.25 \mathrm{mmol} / \mathrm{L}$ dNTPs, and $0.5 \mathrm{U}$ Taq DNA polymerase (Promega, Madison, WI, USA). The PCR cycle conditions were as followed: an initial $94^{\circ} \mathrm{C}$ for 5 minutes, then followed by 34 cycles of $94^{\circ} \mathrm{C}$ for

Table 1 General characteristics of the subjects

\begin{tabular}{lcccccc}
\hline Characteristics & $\begin{array}{c}\text { Osteosarcoma } \\
\text { cases (n) }\end{array}$ & $\%$ & $\begin{array}{c}\text { Cancer-free } \\
\text { controls (n) }\end{array}$ & $\%$ & $\chi^{2}$-value & $p$-value \\
\hline Number & 415 & 49.05 & 431 & 50.95 & & \\
Age (years) & 316 & 76.14 & 308 & 71.46 & & \\
$\quad<20$ & 99 & 23.86 & 123 & 28.54 & & \\
$\quad \geq 20$ & $27.15 \pm 16.53$ & & $29.26 \pm 18.66$ & & & \\
Mean \pm SD & & & & & 2.6718 & 0.1021 \\
Gender (n) & 237 & 57.11 & 222 & 51.51 & & \\
$\quad$ Male & 178 & 42.89 & 209 & 48.49 & & \\
$\quad$ Female & & & & & & \\
Tumor location & 325 & 78.31 & & & & \\
$\quad$ Long tubular bones & 90 & 21.69 & & & & \\
$\quad$ Axial skeleton & 111 & 26.75 & & & & \\
Metastasis & & & & & \\
$\quad$ Yes & 304 & 73.25 & & & & \\
$\quad$ No & & & & & \\
\hline
\end{tabular}

Table 2 The primers, CRS-PCR and PCR-RFLP analysis for MDM2 genetic variants

\begin{tabular}{|c|c|c|c|c|c|c|c|}
\hline SNPs & Primer sequences & $\begin{array}{l}\text { Amplification } \\
\text { fragment (bp) }\end{array}$ & Region & $\begin{array}{c}\text { Annealing } \\
\text { temperature }\left({ }^{\circ} \mathrm{C}\right)\end{array}$ & $\begin{array}{l}\text { Genotype } \\
\text { method }\end{array}$ & $\begin{array}{l}\text { Restriction } \\
\text { enzyme }\end{array}$ & Genotype (bp) \\
\hline \multirow[t]{3}{*}{ c. $44 \mathrm{C}>\mathrm{T}$} & 5'-TGTGCAATACCAACATGTCTGGAC-3' & 218 & Exon2 & 62.5 & CRS-PCR & AvaII & CC:218 \\
\hline & 5'-GCCAGAGGTAGCACACTTTAAGCT-3' & & & & & & CT:218,197,21 \\
\hline & & & & & & & TT:197,21 \\
\hline \multirow[t]{3}{*}{ c. $1002 \mathrm{~T}>\mathrm{C}$} & 5'-GCAAAGTTGCTAGCATTCCTGTG-3' & 243 & Exon11 & 62.0 & PCR-RFLP & $T s p E \mathrm{I}$ & TT:243 \\
\hline & 5'-СССТCTTCAGCTTGTGTTGAGTT-3' & & & & & & TC:243, 157,86 \\
\hline & & & & & & & $\mathrm{CC}: 157,86$ \\
\hline
\end{tabular}

Note: SNPs, single nucleotide polymorphisms; PCR, polymerase chain reaction; CRS-PCR, created restriction site-PCR; PCR-RFLP, PCR-restriction fragment length polymorphism; Underlined nucleotides mark nucleotide mismatches enabling the use of the selected restriction enzymes for discriminating sequence variations. 
30 seconds, annealing at the corresponding temperature (given in Table 2) for 30 seconds and $72^{\circ} \mathrm{C}$ for 30 seconds, and a final extension at $72^{\circ} \mathrm{C}$ for 5 minutes. The PCR products were separated by electrophoresis in $2.0 \%$ agarose gel containing ethidium-bromide and observed under UV light.

\section{Genotyping of MDM2 genetic variants}

The c. $44 \mathrm{C}>\mathrm{T}$ genetic variant in MDM2 gene was genotyped by the created restriction site-PCR (CRS-PCR) method with one of the primers containing a nucleotide mismatch, which enables the use of restriction enzymes for discriminating sequence variations [22-26]. The genotyping of c.1002T $>\mathrm{C}$ genetic variant in $M D M 2$ gene was detected by the PCR-restriction fragment length polymorphism (PCR-RFLP) method. According to the supplier's manual, aliquots of $5 \mu \mathrm{L}$ PCR products were digested with $2 \mathrm{U}$ selected restriction enzyme (MBI Fermentas, St. Leon-Rot, Germany, shown in Table 2) at $37^{\circ} \mathrm{C}$ for 10 hours. The digested products were separated by $2.5 \%$ agarose gel electrophoresis containing ethidium-bromide and observed under UV light. To confirm the genotyping results from CRS-PCR and PCR-RFLP methods, $15 \%$ of random samples were re-analyzed by DNA sequencing method (ABI3730xl DNA Analyzer, Applied Biosystems, Foster City, CA).

\section{Statistical analyses}

The chi-squared $\left(\chi^{2}\right)$ test was utilized to assess the Hardy-Weinberg equilibrium (HWE) in allele and genotype distribution, and general characteristics between OS patients and cancer-free controls. The odds ratios (ORs) and 95\% confidence intervals (95\% CIs) were calculated by unconditional logistic regression and utilized to evaluate the potential associations between MDM2 genetic variants and OS risk. All statistical analyses were analyzed by the Statistical Package for Social Sciences software (SPSS, Windows version release 15.0; SPSS Inc.; Chicago, IL, USA). $P$-values less than 0.05 were considerate as significant level.

\section{Results}

\section{General characteristics of subjects}

In this case-control study, we enrolled 846 Chinese Han subjects. Table 1 shows the general characteristics of OS patients and cancer-free controls. Our data indicate that there are no significant differences between OS patients and cancer-free controls with regarded to gender, sex, tumor location and metastasis.

\section{Identification of MDM2 genetic variants}

Two MDM2 genetic variants (c.44C $>\mathrm{T}$ and c. $1002 \mathrm{~T}>\mathrm{C}$ ) were confirmed through CRS-PCR, PCRRFLP and DNA sequencing methods. As for c. $44 \mathrm{C}>\mathrm{T}$, DNA sequence analyses indicate that this genetic variant is a non-synonymous mutation, which causes by $\mathrm{C}$ to T mutations in exon2 of the human MDM2 gene. This mutation has result into the proline (Pro) to leucine (Leu) amino acid replacement (p.Pro15Leu, reference sequences GenBank IDs: NG_016708.1, NM_002392.4 and NP_002383.2). The AvaII restriction enzyme was selected to digest the PCR amplified products of $\mathrm{c} .44 \mathrm{C}>\mathrm{T}$, and three genotypes were detected consisted of CC genotype (218 bp), CT genotype (218,197 and 21bp) and TT genotype (197 and 21bp, Table 2). As for c.1002T $>$ C, DNA sequence analyses suggest that this genetic variant is a synonymous mutation, which causes by $\mathrm{T}$ to $\mathrm{C}$ mutations in exon 11 of the human MDM2 gene (p. asparagine (Asn) 334Asn, reference sequences GenBank IDs: NG_016708.1, NM_002392.4 and NP_002383.2). The PCR amplified products of c. $1002 \mathrm{~T}>\mathrm{C}$ were digested by $T s p E \mathrm{I}$ restriction enzyme and three genotypes were found, TT genotype (243 bp), TC genotype (243,157 and $86 \mathrm{bp}$ ) and CC genotype (157 and 86 bp, Table 2).

\section{Genotype and allele frequencies}

The genotype and allele frequencies of c. $44 \mathrm{C}>\mathrm{T}$ and c. $1002 \mathrm{~T}>\mathrm{C}$ genetic variants in $M D M 2$ gene are performed in Table 3. The $\mathrm{C}$ allele and $\mathrm{CC}$ genotype frequencies of c.44C $>\mathrm{T}$ and $\mathrm{T}$ allele and $\mathrm{TT}$ genotype frequencies of c. $1002 \mathrm{~T}>\mathrm{C}$ were maximums in OS patients and cancer-free controls. As for c. $44 \mathrm{C}>\mathrm{T}$, we found significantly differences between the allele frequencies of OS patients (C, 64.34\%; T, 35.66\%) and those of cancer-free controls (C, 71.00\%; T, 29.00\%, $\chi^{2}=8.5822, p$ $=0.0034$ ), and the genotype frequencies in OS patients were statistically significant different from those of cancer-free controls $\left(\chi^{2}=13.6661, p=0.0011\right.$, Table 3$)$. As for c. $1002 \mathrm{~T}>\mathrm{C}$, the allele frequencies of OS patients ( $\mathrm{T}$, $69.64 \%$; C, 30.36\%) were statistically significantly different from healthy controls (T, 74.36\%; C, $25.64 \%, \chi^{2}$ $=4.6841, p=0.0304)$. The genotype frequencies of OS patients were not consistent with cancer-free controls, the differences being statistically significant $\left(\chi^{2}=\right.$ $10.4809, p=0.0053$, Table 3 ). The observed genotype frequencies of c. $44 \mathrm{C}>\mathrm{T}$ and c. $1002 \mathrm{~T}>\mathrm{C}$ genetic variants 
were corresponded to HWE in OS patients and cancerfree controls (All $p$-values $>0.05$, Table 3 ).

\section{Association between MDM2 genetic variants and osteosarcoma risk}

Table 4 shows the potential association between $M D M 2$ genetic variants and OS risk. As for c. $44 \mathrm{C}>\mathrm{T}$, we found statistically significantly increased risk of OS in the homozygote comparison (TT versus (vs.) CC: $\mathrm{OR}=2.43,95 \%$ CI $\left.1.49-3.95, \chi^{2}=13.24, p<0.001\right)$, recessive model (TT vs. CT/CC: $\mathrm{OR}=2.34,95 \% \mathrm{CI}$ 1.47-3.73, $\left.\chi^{2}=13.40, p<0.001\right)$ and allele comparison (T vs. C: $\mathrm{OR}=1.36,95 \%$ CI 1.11-1.67, $\chi^{2}=8.58$, $p=0.003$ ). As for c. $1002 \mathrm{~T}>\mathrm{C}$, statistically increased risk of OS were detected in the homozygote comparison (CC vs. TT: OR $=2.38,95 \%$ CI 1.37-4.13, $\chi^{2}=$ 9.91, $p=0.002)$, recessive model (CC vs. TC/TT: OR $=2.38,95 \%$ CI $\left.1.39-4.06, \chi^{2}=10.47, p=0.001\right)$ and allele comparison (C vs. T: OR $=1.27,95 \%$ CI 1.02 $\left.1.56, \chi^{2}=4.68, p=0.030\right)$.

\section{Discussion}

OS is a primary bone tumor and causes from complex interactions between environmental factors and genetic factors. Recently, there are several genetic variants in $M D M 2$ gene have been reported the potential association with OS susceptibility, most of these studies were focused on the rs2279744 (T309G) and rs1690916 genetic variants [16-19]. Toffoli et al., demonstrated that the MDM2 T309G polymorphism was associated with an increased risk of developing osteosarcomas (GG vs. TT: OR $=2.09$, 95\% CI 1.153.78). It provides evidence supporting the association of MDM2 SNP309 $\mathrm{T}>\mathrm{G}$ with high-grade osteosarcoma risk in females (GG vs. TT: OR $=4.26$; $95 \%$ CI 1.6111.25) [16]. Mirabello et al., observed that MDM2 rs1690916 polymorphism was significantly associated with a decreased risk of OS after correction (OR $=0.62,95 \%$ CI 0.45 -0.85, $p$-adjust $=0.026$ ). Three intronic SNPs were significantly associated with an increased risk of OS before correction $(\mathrm{ORs}=1.6-1.8$,

Table 3 The genotype and allele frequencies of MDM2 genetic variants in the osteosarcoma (OS) cases and cancer-free controls

\begin{tabular}{|c|c|c|c|c|c|c|c|c|c|c|c|c|c|c|}
\hline \multirow{3}{*}{ Groups } & \multicolumn{7}{|c|}{ c. $44 \mathrm{C}>\mathrm{T}$} & \multicolumn{7}{|c|}{ c. $1002 \mathrm{~T}>\mathrm{C}$} \\
\hline & \multicolumn{3}{|c|}{ Genotype frequencies (\%) } & \multicolumn{4}{|c|}{ Allele frequencies (\%) } & \multicolumn{3}{|c|}{ Genotype frequencies (\%) } & \multicolumn{4}{|c|}{ Allele frequencies (\%) } \\
\hline & $\mathrm{CC}$ & $\mathrm{CT}$ & TT & $\mathrm{C}$ & $\mathrm{T}$ & $\chi^{2}$-value & $p$-value & TT & $\mathrm{TC}$ & $\mathrm{CC}$ & $\mathrm{T}$ & $\mathrm{C}$ & $\chi^{2}$-value & $p$-value \\
\hline $\begin{array}{c}\text { Cases } \\
(\mathrm{n}=415)\end{array}$ & $\begin{array}{c}179 \\
(43.13)\end{array}$ & $\begin{array}{c}176 \\
(42.41)\end{array}$ & $\begin{array}{c}60 \\
(14.46)\end{array}$ & $\begin{array}{c}534 \\
(64.34)\end{array}$ & $\begin{array}{c}296 \\
(35.66)\end{array}$ & 855 & 0.3034 & $\begin{array}{c}208 \\
(50.12)\end{array}$ & $\begin{array}{c}162 \\
(39.04)\end{array}$ & $\begin{array}{c}45 \\
(10.84)\end{array}$ & $\begin{array}{c}578 \\
(69.64)\end{array}$ & $\begin{array}{c}252 \\
(30.36)\end{array}$ & 2.4520 & 0.2935 \\
\hline $\begin{array}{l}\text { Controls } \\
(\mathrm{n}=431)\end{array}$ & $\begin{array}{c}210 \\
(48.72)\end{array}$ & $\begin{array}{c}192 \\
(44.55)\end{array}$ & $\begin{array}{c}29 \\
(6.73)\end{array}$ & $\begin{array}{c}612 \\
(71.00)\end{array}$ & $\begin{array}{c}250 \\
(29.00)\end{array}$ & 7 & 0. & $\begin{array}{c}231 \\
(53.60)\end{array}$ & $\begin{array}{c}179 \\
(41.53)\end{array}$ & $\begin{array}{c}21 \\
(4.87)\end{array}$ & $\begin{array}{c}641 \\
(74.36)\end{array}$ & $\begin{array}{c}221 \\
(25.64)\end{array}$ & 3.4298 & 0.1800 \\
\hline \multirow[t]{2}{*}{$\begin{array}{c}\text { Total } \\
(\mathrm{n}=846)\end{array}$} & $\begin{array}{c}389 \\
(45.98)\end{array}$ & $\begin{array}{c}368 \\
(43.50)\end{array}$ & $\begin{array}{c}89 \\
(10.52)\end{array}$ & $\begin{array}{c}1146 \\
(67.73)\end{array}$ & $\begin{array}{c}546 \\
(32.27)\end{array}$ & 0.0202 & 0.9899 & $\begin{array}{c}439 \\
(51.89)\end{array}$ & $\begin{array}{c}341 \\
(40.31)\end{array}$ & $\begin{array}{c}66 \\
(7.80)\end{array}$ & $\begin{array}{c}1219 \\
(72.04)\end{array}$ & $\begin{array}{c}473 \\
(27.96)\end{array}$ & 0.0004 & 0.9998 \\
\hline & \multicolumn{3}{|c|}{$\chi^{2}=13.6661, p=0.0011$} & \multicolumn{4}{|c|}{$\overline{\chi^{2}=8.5822, p=0.0034}$} & $\chi^{2}=10$ & $4809, p=$ & 0.0053 & \multicolumn{4}{|c|}{$\overline{\chi^{2}}=4.6841, p=0.0304$} \\
\hline
\end{tabular}

The chi-squared $\left(\chi^{2}\right)$ test was utilized to assess the Hardy-Weinberg equilibrium (HWE) in allele and genotype distribution, and general characteristics between OS patients and cancer-free controls.

Table 4 The association between osteosarcoma (OS) risk and MDM2 genetic variants

\begin{tabular}{|c|c|c|c|c|}
\hline \multirow{2}{*}{ SNPs } & \multirow{2}{*}{ Comparisons } & \multicolumn{3}{|c|}{ Test of association } \\
\hline & & OR $(95 \% \mathrm{CI})$ & $\chi^{2}$-value & $p$-value \\
\hline \multirow[t]{5}{*}{ c. $44 \mathrm{C}>\mathrm{T}$} & Homozygote comparison (TT vs. CC) & $2.43(1.49-3.95)$ & 13.24 & $<0.001$ \\
\hline & Heterozygote comparison (CT vs. CC) & $1.08(0.89-1.43)$ & 0.25 & 0.618 \\
\hline & Dominant model (TT/CT vs. CC) & $1.25(0.96-1.64)$ & 2.66 & 0.103 \\
\hline & Recessive model (TT vs. CT/CC) & $2.34(1.47-3.73)$ & 13.40 & $<0.001$ \\
\hline & Allele contrast ( $\mathrm{T} v s . \mathrm{C})$ & $1.36(1.11-1.67)$ & 8.58 & 0.003 \\
\hline \multirow[t]{5}{*}{ c. $1002 \mathrm{~T}>\mathrm{C}$} & Homozygote comparison (CC vs. TT) & $2.38(1.37-4.13)$ & 9.91 & 0.002 \\
\hline & Heterozygote comparison (TC vs. TT) & $1.01(0.76-1.33)$ & 0.00 & 0.972 \\
\hline & Dominant model (CC/TC vs. TT) & $1.15(0.88-1.51)$ & 1.02 & 0.312 \\
\hline & Recessive model (CC vs. TC/TT) & $2.38(1.39-4.06)$ & 10.47 & 0.001 \\
\hline & Allele contrast $(\mathrm{C} v s . \mathrm{T})$ & $1.27(1.02-1.56)$ & 4.68 & 0.030 \\
\hline
\end{tabular}

$\overline{\text { SNPs, single nucleotide polymorphisms; OR, odds ratio; CI, confidence interval; vs., versus. }}$ 
$p=0.008-0.02) . \quad$ The MDM2 T309G polymorphism was marginally non-significantly associated with an increased risk of OS $(\mathrm{OR}=1.31,95 \%$ CI 0.97-1.77, $p=0.07$ ). Mirabello and his colleagues indicated that $M D M 2$ gene was found to be significantly associated with OS $(p=0.016)$, but not after correction for multiple tests [17]. Naumov et al., reported that the allele A of MDM2 rs1690916 polymorphism decreased the disease risk and it could be regarded as protective factor $(\mathrm{OR}=0.39,95 \%$ CI $0.19-0.78)$. These findings confirmed that the $M D M 2$ gene was involved in bone tumor development [19]. Cai conducted a meta-analysis to systematically examine the association between these functional SNPs and sarcoma risk. Compared to TT genotype, carriers of TG and GG genotypes showed a $34 \%$ increased risk to develop sarcomas. Results from this meta-analysis indicate that the functional MDM2 T309G genetic variant may play a more important role in carcinogenesis of sarcoma including OS [18]. In the present study, we demonstrate that the c. $44 \mathrm{C}>\mathrm{T}$ and c. $1002 \mathrm{~T}>\mathrm{C}$ genetic variants in $M D M 2$ gene are statistically significant correlated with the susceptibility to OS through association analysis in 415 OS patients and 431 cancer-free controls. We found significant differences in allele and genotype frequencies between OS patients and cancer-free controls (All $p$-values $<0.05$,
Table 3). As for c. $44 \mathrm{C}>\mathrm{T}$, comparing with $\mathrm{CC}$ genotype and $\mathrm{CT} / \mathrm{CC}$ carriers, the TT genotype was statistically associated with the increased risk of OS ( $p$-values $<0.05$ ). As for $\mathrm{c} .1002 \mathrm{~T}>\mathrm{C}$, comparing with TT genotype and TC/TT carriers, the CC genotype was statistically associated with the increased risk of OS ( $p$-values $<0.05$ ). Our data indicate that the $\mathrm{T}$ allele and TT genotype of c. $44 \mathrm{C}>\mathrm{T}$ and $\mathrm{C}$ allele and $\mathrm{CC}$ genotype of c. $1002 \mathrm{~T}>\mathrm{C}$ are increased risk factors for the susceptibility to OS in Chinese Han population (Table 4). Up to date, this is the first report about the potential association of c. $44 \mathrm{C}>\mathrm{T}$ and c. $1002 \mathrm{~T}>\mathrm{C}$ genetic variants in MDM2 gene with OS susceptibility. Evidence from this study indicates that $M D M 2$ genetic variants could be utilized as molecular biomarkers for assessing OS susceptibility. Our findings add to the growing literatures that suggest that the association between $M D M 2$ genetic variants and OS susceptibility is complex and incompletely understood. Future functional studies on different ethnic populations are essential to confirm these findings and to elucidate the underling molecular mechanism of genetic influence on the pathogenesis of OS.

\section{Conflict of interests}

The authors have no conflict of interests.

\section{References}

1. Dorfman HD, Czerniak B (1995) Bone cancers. Cancer 75: 203-210.

2. Mirabello L, Troisi RJ, Savage SA (2009) Osteosarcoma incidence and survival rates from 1973 to 2004: data from the Surveillance, Epidemiology, and End Results Program. Cancer 115: 1531-1543.

3. Hameed M, Dorfman H (2011) Primary malignant bone tumors-recent developments. Semin Diagn Pathol 28: 86-101.

4. Wang LL (2005) Biology of osteogenic sarcoma. Cancer $J$ 11: 294-305.

5. Mirabello L, Berndt SI, Seratti GF, Burdett L, Yeager M, Chowdhury S, Teshome K, Uzoka A, Douglass C, Hayes RB, Hoover RN, Savage SA (2010) Genetic variation at chromosome 8q24 in osteosarcoma cases and controls. Carcinogenesis 31: 1400-1404.

6. Wittig JC, Bickels J, Priebat D, Jelinek J, Kellar-Graney K, Shmookler B, Malawer MM (2002) Osteosarcoma: a multidisciplinary approach to diagnosis and treatment. Am Fam Physician 65: 1123-1132.

7. Kager L, Zoubek A, Potschger U, Kastner U, Flege
S, Kempf-Bielack B, Branscheid D, Kotz R, SalzerKuntschik M, Winkelmann W, Jundt G, Kabisch H, Reichardt P, Jurgens H, Gadner H, Bielack SS (2003) Primary metastatic osteosarcoma: presentation and outcome of patients treated on neoadjuvant Cooperative Osteosarcoma Study Group protocols. J Clin Oncol 21: 2011-2018.

8. Ries LAG and SEER Program (National Cancer Institute (U.S.)). (1999) Cancer incidence and survival among children and adolescents: United States SEER program 1975-1995 /[edited by Lynn A. Gloecker Ries. et al.]. National Cancer Institute, SEER Program, Bethesda, MD. http://seer.cancer.gov/publications/childhood/

9. Savage SA, Woodson K, Walk E, Modi W, Liao J, Douglass C, Hoover RN, Chanock SJ (2007) Analysis of genes critical for growth regulation identifies Insulinlike Growth Factor 2 Receptor variations with possible functional significance as risk factors for osteosarcoma. Cancer Epidemiol Biomarkers Prev 16: 1667-1674.

10. Fuchs B, Zhang K, Schabel A, Bolander ME, Sarkar G (2001) Identification of twenty-two candidate markers 
for human osteogenic sarcoma. Gene 278: 245-252.

11. Salinas-Souza C, Petrilli AS, de Toledo SR (2010) Glutathione S-transferase polymorphisms in osteosarcoma patients. Pharmacogenet Genomics 20: 507-515.

12. Wang W, Wang J, Song H, Liu J, Song B, Cao X (2011) Cytotoxic T-lymphocyte antigen-4 $+49 \mathrm{G} / \mathrm{A}$ polymorphism is associated with increased risk of osteosarcoma. Genet Test Mol Biomarkers 15: 503-506.

13. Liu Y, He Z, Feng D, Shi G, Gao R, Wu X, Song W, Yuan W (2011) Cytotoxic T-lymphocyte antigen-4 polymorphisms and susceptibility to osteosarcoma. DNA Cell Biol 30: 1051-1055.

14. Liu Y, Lv B, He Z, Zhou Y, Han C, Shi G, Gao R, Wang C, Yang L, Song H, Yuan W (2012) Lysyl oxidase polymorphisms and susceptibility to osteosarcoma. PLoS One 7: e41610.

15. Caronia D, Patino-Garcia A, Perez-Martinez A, Pita G, Moreno LT, Zalacain-Diez M, Molina B, Colmenero I, Sierrasesumaga L, Benitez J, Gonzalez-Neira A (2011) Effect of ABCB1 and ABCC3 polymorphisms on osteosarcoma survival after chemotherapy: a pharmacogenetic study. PLoS One 6: e26091.

16. Toffoli G, Biason P, Russo A, De Mattia E, Cecchin E, Hattinger CM, Pasello M, Alberghini M, Ferrari C, Scotlandi K, Picci P, Serra M (2009) Effect of TP53 Arg72Pro and MDM2 SNP309 polymorphisms on the risk of high-grade osteosarcoma development and survival. Clin Cancer Res 15: 3550-3556.

17. Mirabello L, Yu K, Berndt SI, Burdett L, Wang Z, Chowdhury S, Teshome K, Uzoka A, Hutchinson A, Grotmol T, Douglass C, Hayes RB, Hoover RN, Savage SA (2011) A comprehensive candidate gene approach identifies genetic variation associated with osteosarcoma. BMC Cancer 11: 209.

18. Cai X, Yang M (2012) The functional MDM2 T309G genetic variant but not P53 Arg72Pro polymorphism is associated with risk of sarcomas: a meta-analysis. $J$ Cancer Res Clin Oncol 138: 555-561.

19. Naumov VA, Generozov EV, Solovyov YN, Aliev MD, Kushlinsky NE (2012) Association of FGFR3 and MDM2 gene nucleotide polymorphisms with bone tumors. Bull Exp Biol Med 153: 869-873.

20. Wunder JS, Eppert K, Burrow SR, Gokgoz N, Bell RS, Andrulis IL (1999) Co-amplification and overexpression of CDK4, SAS and MDM2 occurs frequently in human parosteal osteosarcomas. Oncogene 18: 783-788.

21. Mejia-Guerrero S, Quejada M, Gokgoz N, Gill M, Parkes RK, Wunder JS, Andrulis IL (2010) Characterization of the 12q15 MDM2 and 12q13-14 CDK4 amplicons and clinical correlations in osteosarcoma. Genes Chromosomes Cancer 49: 518-525.

22. Haliassos A, Chomel JC, Tesson L, Baudis M, Kruh J, Kaplan JC, Kitzis A (1989) Modification of enzymatically amplified DNA for the detection of point mutations. Nucleic Acids Res 17: 3606.

23. Yuan ZR, Li J, Li JY, Gao X, Xu SZ (2013) SNPs identification and its correlation analysis with milk somatic cell score in bovine MBL1 gene. Mol Biol Rep 40: $7-12$.

24. Yuan ZR, Li JY, Li J, Zhang LP, Gao X, Gao HJ, Xu SZ (2012) Investigation on BRCA1 SNPs and its effects on mastitis in Chinese commercial cattle. Gene 505: 190194.

25. Yuan ZR, Li JY, Li J, Gao X, Xu SZ (2013) Effects of DGAT1 gene on meat and carcass fatness quality in Chinese commercial cattle. Mol Biol Rep 40: 19471954.

26. Zhao CJ, Li N, Deng XM (2003) The establishment of method for identifying SNP genotype by CRS-PCR. $Y i$ Chuan 25: 327-329. 